\title{
Characteristics Strength of groundnut shell ash (GSA) and Ordinary Portland cement (OPC) blended Concrete in Nigeria.
}

\author{
Buari T.A, Ademola S.A, Ayegbokiki S.T \\ Department of Building Technology, Federal Polytechnic, P.M.B 231, Ede, State of Osun, Nigeria. \\ Department of Building Technology, Onus State Polytechnic, Iree, State of Osun, Nigeria. \\ Department of Building Technology, Federal Polytechnic, Ede.
}

\begin{abstract}
The experimental work evaluates the potentials of groundnut shell ash (GSA) as a partial replacement for ordinary Portland cement (OPC) in concrete. Chemical analysis of the ash was carried out to ascertain it cementing properties and the partial replacement of OPC by GSA was varied from $0 \%$ to $20 \%$ in the concrete. A total of 80 specimens of the GSA/OPC concrete cubes of $150 \mathrm{~mm}$ dimension were cured in water for 21, 28 and 56 days and the compressive and splitting tensile strengths determined. The results show that the compressive strengths of the control $(0 \%)$ and those of other percentage combinations increased with curing age but decreased with increased GSA percentage. Though, Characteristics strengths revealed that the OPC/GSA concrete of $10 \%$ replacement performed better in comparison to the acceptable standard and would be more suitable for mass concrete production.
\end{abstract}

Key words: - Blended concrete, cement, cementing properties, groundnut shell ash.

\section{INTRODUCTION}

The continuous increase in the price of Portland cement is attributed to the insufficient production rate of the raw materials when compared with the demand rate in the construction industries [1]. The growing concern of resource depletion and global pollution has challenged many researchers and engineers for continuous search for alternative supplementary materials, which may have hydraulic/Pozzolanic properties with a view to investigating their usefulness as a construction material and their indispensable to the reduction of pollution, energy and carbon dioxide generated in the production of cement [2].Since OPC is typically the most expensive constituent of concrete, the replacement of proportion of it with Groundnut Shell Ash (GSA) will improve concrete affordability particularly for low-cost housing in Nigeria. The use of GSA will also contribute to the production of concrete of a higher quality at lower cost and reduces the environmental problem resulting from the accumulation of the shells in a large quantity in a particular area in Nigeria.

With these reasons, this work evaluates the characteristics strength performance of groundnut shell ash (GSA) as a partial replacement for ordinary Portland cement (OPC) in concrete. Various percentages of GSA $(0 \%, 5 \%, 10 \%, 15 \%, 20 \%$.) were used to produce the concrete and GSA/OPC concrete's characteristics performance were measured after curing in water for 21,28 and 56 days hydration periods by conducting Compressive and splitting tensile tests on the hardened concretes.

The choice of the percentage substitutions (GSA) used and hydration period were based on a similar research carried out by [3] on Bambara Groundnut Shell Ash which, reported that 10\% substitution of ash with cement in blended concrete was acceptable compared with required standards and [4-5] with their experiments extended beyond 28 days hydration period.

\section{MATERIALS AND METHOD}

The materials used in this project were groundnut shell ash, sand (fine aggregate), granite (coarse aggregate), cement and clean water as the curing medium. The concrete comprised of ordinary Portland cement (OPC), groundnut shell ash. (G.S.A), fine aggregate, coarse aggregate and water at design proportions.

Groundnut shell used for this research was sourced from Ogbomosho L.G.A. of Oyo State. The shells was collected in bags and transported to Ibadan and later moved to the Federal institute for Industrial research (FIIRO) Lagos, where the burning and grinding were carried out. Consequently, the ashes were collected in bags and were taken to the Concrete and Structural Laboratory of the Department of Building, Federal Polytechnic, Ede. The sieve analysis, moisture content and the specific gravity were carried out on GSA at the Soil Mechanics Laboratory of the Department of Building, Federal Polytechnic, Ede. The results of physical properties, specific gravity, chemical analysis and sieve analysis of GSA are presented in tables 1, 2, 3 and 4.respectively.

The Coarse aggregate used was granite stone. It was of high quality and free of deleterious organic matter and the $20 \mathrm{~mm}$ maximum sieve size were used. Also, the fine aggregate used was white sand obtained 
from river with $4.75 \mathrm{~mm}$ maximum sieve size. Before the sand was used it was dried to remove the moisture content so that it will not increase the water content in the concrete mix. Dangote brand of Ordinary Portland Cement was used as the main binder. It conforms to type 1 cement as specified by [6].

\subsection{Mixes}

A concrete mix of ratio 1:2:4 was adopted for the production of concrete cubes at water / cement ratio of 0.6 . Cement content was replaced at $5 \%, 10 \%, 15 \%$ and $20 \%$ with GSA. The adopted substitution levels was based on previous similar works conducted by $[7,8,5]$ which Recommends between $10 \% 40 \%$ as the most suitable replacement level for Blended concrete. The moulds used were cleaned with black engine oil to prevent the development of bond between the mould and the concrete. The freshly mixed concrete was scooped into the mould. Each mould was filled in three layers with the concrete; each layer was rammed 25 times with a tamping rod. $150 \mathrm{~mm} \times 150 \mathrm{~mm} \times 150 \mathrm{~mm}$ cubes were produced for the tests. A total of 80 cubes were cast. Concrete cubes were stripped from the mould carefully after 24 hours of the concrete setting under air. All the cubes were cured in water for hydration period of 21, 28 and 56 days respectively. Average of three cubes was crushed for each test. The results of the analysis are shown in Tables 5and 6 and Figures 2.0, 2.1, 3.0 and 3.1.

\subsection{Setting Time}

Values obtained as initial setting time for OPC and OPC/GSA pastes were 2 hours 35 minutes and 3 hours 20 minutes respectively. Final setting time values were obtained for OPC and OPC/GSA pastes as 3 hours 20 minutes and 4 hours 22 minutes. The setting time values obtained were within the recommended range of 30 minutes to 10 hours stipulated by [9] and were in close agreement with the work of [10].

\subsection{Curing Condition}

Curing condition of concrete influences its hydration process. For full hydration of binder and strength development in the concrete the continuous, longer and moist curing is required. In this work, the Initial curing condition which affects the characteristics strength of concrete or mortar were carefully done in curing tank with samples totally immersed in water for maximum of 56 day.

\subsection{Splitting Tensile Test}

Splitting tensile test was conducted at the Mechanical Laboratory of the Federal Polytechnic, Ede After the specimens had been cured for the proper length of time in the water tank, the immersed specimens were taken out from water and allowed to dry.

The machine was set for the required range and diametrical lines was drawn on the two ends of the specimen to ensure that they are on the same axial place, after noting the weight and dimension of the specimen. A plywood strip was placed on the lower plate, then the specimen was placed above the lower plate and the other plywood strip was placed above the specimen. The specimen was loaded continuously without shock at uniform rates until failure occurred and the failure load was recorded.

The results is given in table 6 The splitting tensile strength was calculated using the formula

$\mathrm{Tsp}=2 \mathrm{P} / \mathrm{pi} \mathrm{DL}$

Where, $\quad \mathrm{P}=$ applied load

$\mathrm{D}=$ diameter of the specimen

$\mathrm{L}=$ length of the specimen

\subsection{Compressive Strength Test}

Before crushing, the cubes were brought out of the water and kept for exact1y 30 minutes for the water to drip off. They were then taken to the crushing machine in accordance with [11].The cubes were crushed a result of the load applied by the crushing machine and the readings were taken.

Compressive Stress $=\quad$ Applied Load $(\mathrm{N})$

Cross sectional Area of specimen $\left(\mathrm{mm}^{2}\right)$

\subsection{Physical and Chemical Analysis of Groundnut Shell Ash (GSA)}

\section{RESULTS AND DISCUSSIONS}

Table 1: Physical Properties of Groundnut Shell Ash

\begin{tabular}{|l|l|}
\hline Moisture content & $0.42 \%$ \\
\hline Specific gravity & 1.54 \\
\hline
\end{tabular}

The Specific gravity of GSA is being 1.54 . This value is less than 1.85 and 1.90 reported by [10] and [12] for GHA and Pulverised Fuel Ash respectively. These values are less than average value of 3.15 for 
Portland cement. This means that a considerable greater volume of cementitious materials (GSA) will result from mass replacement. The moisture content is in agreement with value reported by [10] which was $0.43 \%$.

Table 2: Result of specific gravity of G.S.A

\begin{tabular}{lll}
\hline $\begin{array}{l}\text { Sample } \\
\text { Weight }\end{array}$ & Test A & Test B \\
\hline W1 & 25.60 & 25.30 \\
W2 & 60.12 & 59.59 \\
W3 & 80.20 & 80.10 \\
W4 & 68.24 & 68.00 \\
G & 1.54 & 1.55 \\
\hline
\end{tabular}

\section{$S . G=\frac{(\mathrm{w} 2-\mathrm{w} 1)}{(\mathrm{w} 4-\mathrm{w} 1)-(\mathrm{w} 3-\mathrm{w} 2)}$}

Where: $\quad W 1=$ weight of empty flask $\mathrm{W} 3=$ weight of flask + cement + water Average $=$

1.54
W2 = weight of flask + cement

W4= weight of flask + water

Table 3: Chemical Analysis of Groundnut Shell Ash and OPC

\begin{tabular}{|l|l|l|}
\hline Constituent & \% Composition $(\mathrm{GSA})$ & \% Composition (OPC) \\
\hline Ferrous oxide $\left(\mathrm{Fe}_{2} \mathrm{O}_{3}\right)$ & 1.80 & 4.60 \\
\hline Silica $\left(\mathrm{SiO}_{2}\right)$ & 16.21 & 22.00 \\
\hline Calcium Oxide $(\mathrm{CaO})$ & 8.69 & 62.00 \\
\hline Aluminum Oxide $\left(\mathrm{Al}_{2} \mathrm{O}_{3}\right)$ & 5.93 & 5.03 \\
\hline Magnesium Oxide $(\mathrm{MgO})$ & 6.74 & 2.06 \\
\hline Sodium Oxide $\left(\mathrm{Na}_{2} \mathrm{O}\right)$ & 9.02 & 0.19 \\
\hline Potassium $\left.\mathrm{Oxide}_{2} \mathrm{O}\right)$ & 15.73 & 0.40 \\
\hline Sulphite $\left(\mathrm{SO}_{3}-\right)$ & 6.21 & 1.43 \\
\hline I.L & 4.80 & 2.82 \\
\hline
\end{tabular}

The results above indicate that GSA contains most of oxides found in ordinary Portland cement. The $\mathrm{CaO}$ composition of ordinary Portland cement was higher than that of the Groundnut Shell ash while $\mathrm{K}_{2} \mathrm{O}$ composition of GSA was also higher than that found in ordinary Portland cement. The result of the chemical analysis is similar to the works conducted by [7] with the total percentage of Iron Oxide, Silicon Oxide and Aluminum Oxide is less than the minimum of $70 \%$ specified by for pozzolanas [13].

Table 4: Sieve Analysis result for G.S.A

\begin{tabular}{lllll}
\hline Sieve size & Weight retained & \%Retained & Cumulative retained & \%passing \\
\hline 1.180 & 0.26 & 0.09 & 0.09 & 99.91 \\
0.850 & 0.43 & 0.15 & 0.24 & 99.76 \\
0.600 & 3.31 & 1.17 & 1.41 & 98.59 \\
0.425 & 29.34 & 10.40 & 11.81 & 88.19 \\
0.300 & 189.00 & 67.02 & 78.83 & 21.17 \\
0.150 & 56.49 & 20.03 & 98.86 & 1.14 \\
0.075 & 3.17 & 1.12 & 100.00 & 0.00 \\
Total & 282.00 & 100.00 & - & - \\
\hline
\end{tabular}

$\%$ retained on each sieve $=\frac{\text { weigth of soil retained in sieve }}{\text { total weigth of soil }} * 100 \%$

Cumulative retained $=$ Sum of percentages retained on all coarser sieve

$\%$ Passing $=100 \%$ - cumulative

$\mathrm{C}_{\mathrm{u}}=\frac{\mathrm{D} 60}{\mathrm{D} 10}$, coefficient of uniformity

$\mathrm{Cc}=\frac{(\mathrm{D} 30)^{\wedge} 2}{\mathrm{D} 10 * \mathrm{D} 60}$, coefficient of curvature 


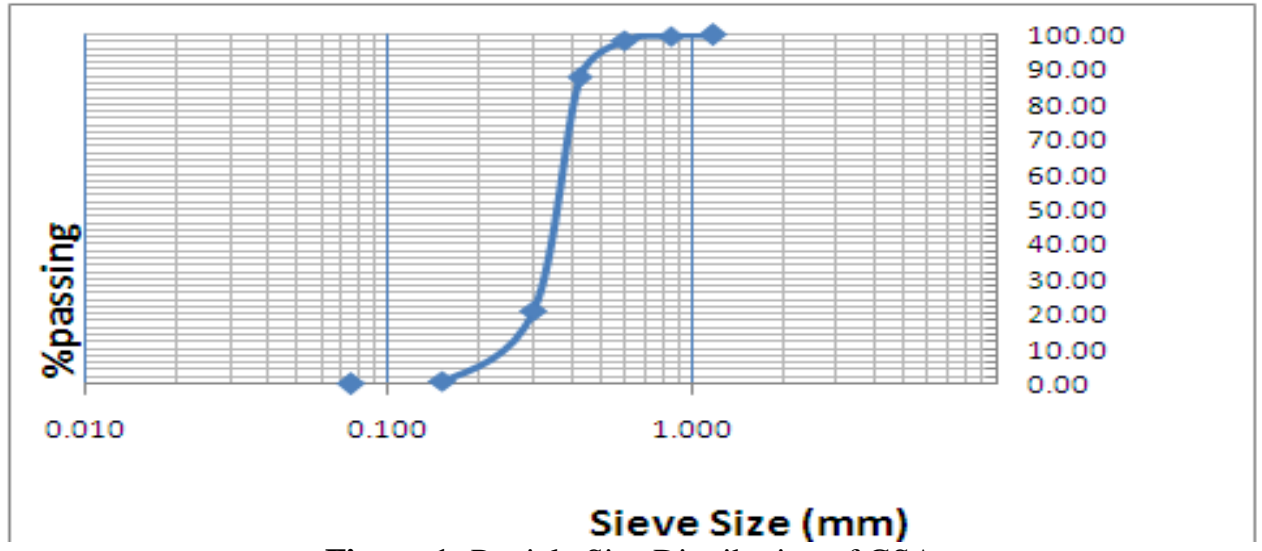

Figure 1: Particle Size Distribution of GSA

From graph,

$\mathrm{D}_{10}=0.24 \mathrm{~mm} \quad, \mathrm{D} 30=0.33 \mathrm{~mm} \quad, \quad \mathrm{D} 60=0.38$

$\mathrm{Cu}=\frac{0.38}{0.24}=1.58 \quad, \quad \mathrm{Cc}=\frac{(0.33) \wedge}{0.24 * 0.38}=1.19$

\subsection{Compressive Test}

Table 5: Compressive Test Result for the Concrete

\begin{tabular}{|l|l|l|l|}
\hline \multirow{2}{*}{ Description } & \multicolumn{3}{|l|}{ Compressive Strength In $\left(\mathrm{N} / \mathrm{mm}^{2}\right)$} \\
\cline { 2 - 4 } & 21days & 28days & 56days \\
\hline $\mathrm{CN}_{0}$ & 16.91 & 23.9 & 24.33 \\
\hline $\mathrm{CN}_{5}$ & 18.32 & 20.33 & 19.4 \\
\hline $\mathrm{CN}_{10}$ & 16.35 & 21.34 & 23.44 \\
\hline $\mathrm{CN}_{15}$ & 13.38 & 15.34 & 16.89 \\
\hline $\mathrm{CN}_{20}$ & 12.36 & 15.00 & 14.79 \\
\hline
\end{tabular}

$\mathrm{CN}_{0}, \mathrm{CN}_{5}, \mathrm{CN}_{10}, \mathrm{CN} 15$ and $\mathrm{CN}_{20}$ are; $0 \%, 5 \%, 10 \%, 15 \%$ and $20 \% \mathrm{GSA}$ replacements

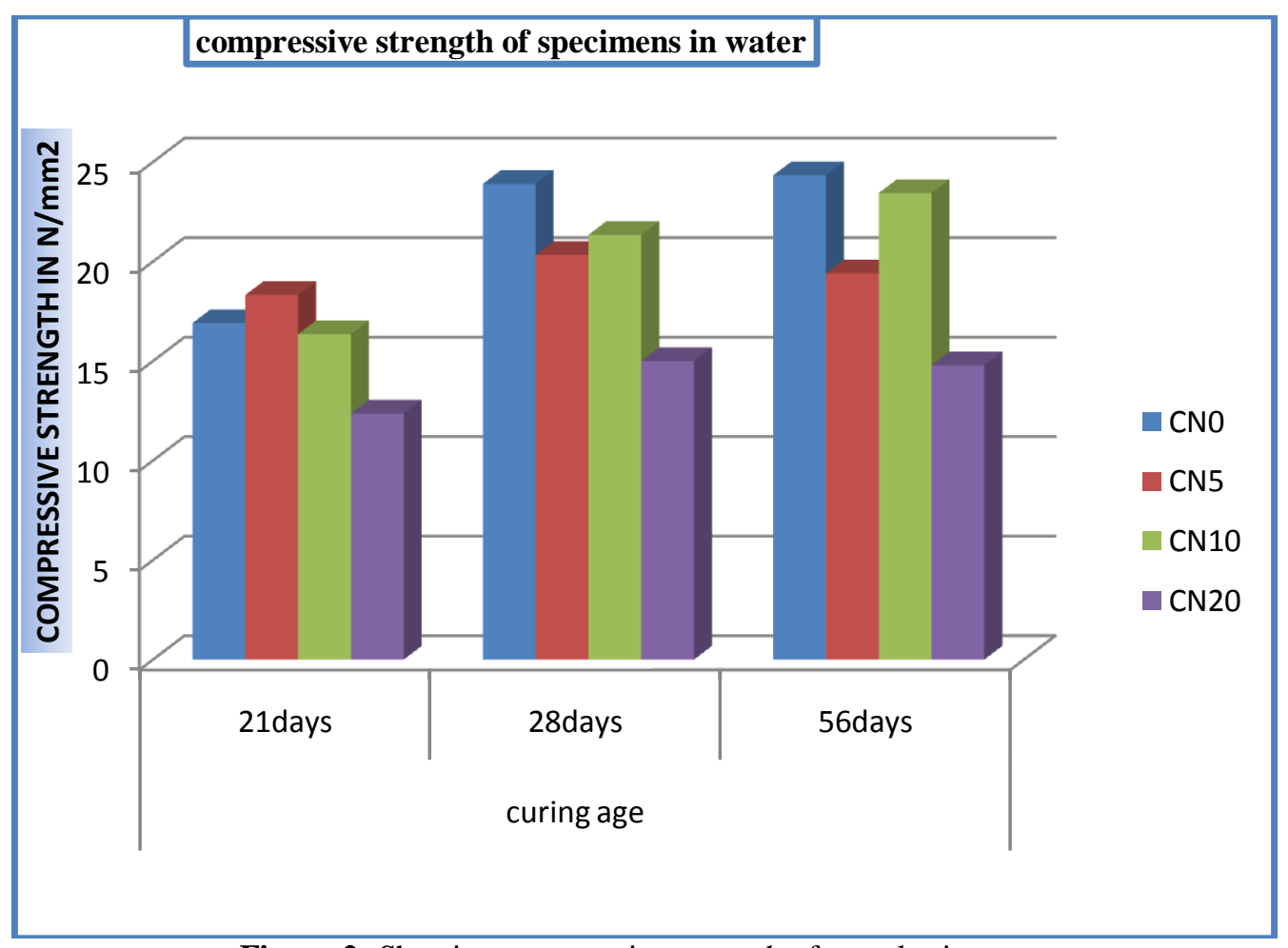

Figure 2: Showing compressive strength of samples in water 


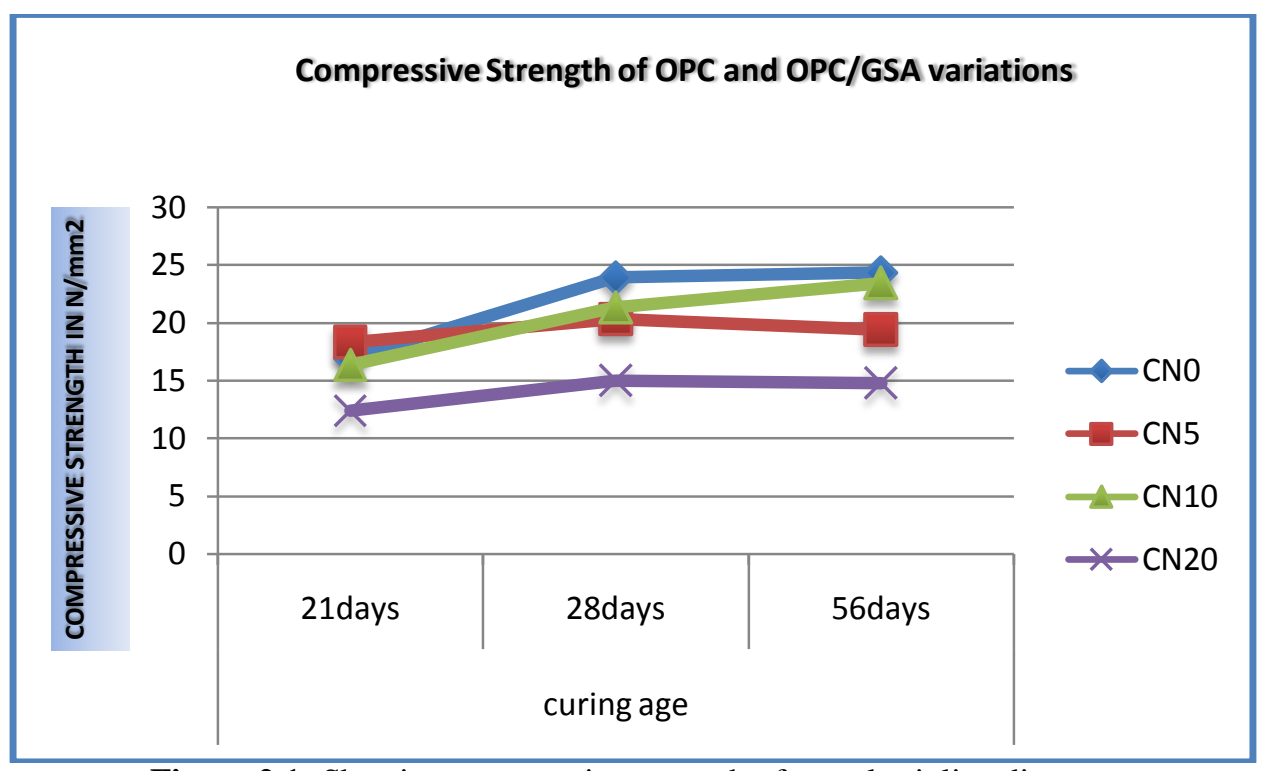

Figure 2.1: Showing compressive strength of samples inline diagram

The results above shows that Compressive strength for the control was $16.91 \mathrm{~N} / \mathrm{MM}^{2}, 23.90 \mathrm{~N} / \mathrm{MM}^{2}$ and $24.33 \mathrm{~N} / \mathrm{MM}^{2}$ for 21,28 and56 days respectively while it was $12.36 \mathrm{~N} / \mathrm{MM}^{2}, 14.00 \mathrm{~N} / \mathrm{MM}^{2}$ and $14.79 \mathrm{~N} / \mathrm{MM}^{2}$ for $20 \%$ GSA replacement. The results indicate that for the control (0\% GSA content) and for each cement/GSA combination, the compressive strength increases as the age of the concrete increases. This is due to hydration of cement. The control had the highest rate of early strength development with 10\% GSA/OPC replacement in close contact with consistent rate of strength development. The results shows that their strength improves with age since pozzolanas react more slowly than cement due to variation in their constituent's composition. The pattern of this study was similar to [7,4,5], they reported that cement blended with pozzolanas would produce 65 to $95 \%$ strength of OPC concrete in 28 days. Further, they reported that the replacement of ordinary Portland cement by a Pozzolanic material usually has beneficial effects on cement's durability at ages up to 1.5 years. At age 56 days, the compressive strength was $24.33 \mathrm{~N} / \mathrm{MM}^{2}, 19.40 \mathrm{~N} / \mathrm{MM}^{2}, 23.44 \mathrm{~N} / \mathrm{MM}^{2}, 16.89 \mathrm{~N} / \mathrm{MM}^{2}$ and 14.79 $\mathrm{N} / \mathrm{MM}^{2}$. The results show that for the same age, the compressive strength decreases as the proportion of GSA increases. This is because the GSA possesses little cementing properties compared to a Portland cement, [7]. As previous described by $[14,1]$, a percentage replacement of $10 \%$ with GSA will be adequate for good concrete work

\subsection{Splitting Tensile Test}

Table 6: Splitting Tensile Test Result for the Concrete.

\begin{tabular}{|l|l|l|l|l|}
\hline Samples & GSA\% & 21days & 28days & 56days \\
\hline $\mathrm{TN}_{0}$ & $0 \%$ & 2.00 & 2.69 & 3.13 \\
\hline $\mathrm{TN}_{5}$ & $5 \%$ & 1.89 & 2.46 & 2.94 \\
\hline $\mathrm{TN}_{10}$ & $10 \%$ & 1.64 & 2.11 & 2.76 \\
\hline $\mathrm{TN}_{15}$ & $15 \%$ & 1.35 & 1.97 & 2.84 \\
\hline $\mathrm{TN}_{20}$ & $20 \%$ & 1.19 & 1.87 & 2.54 \\
\hline
\end{tabular}

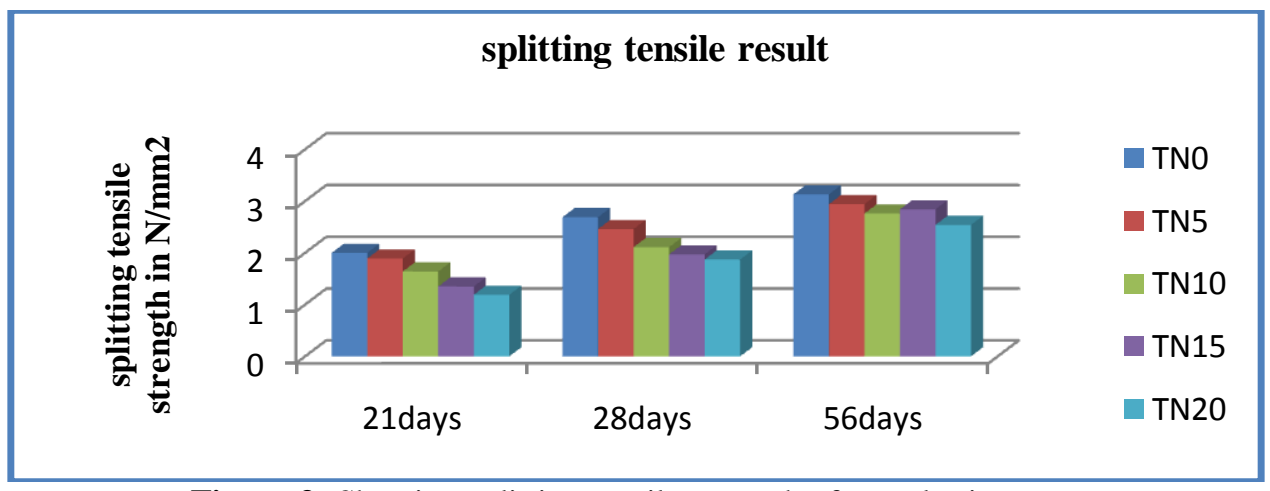

Figure 3: Showing splitting tensile strength of samples in water 


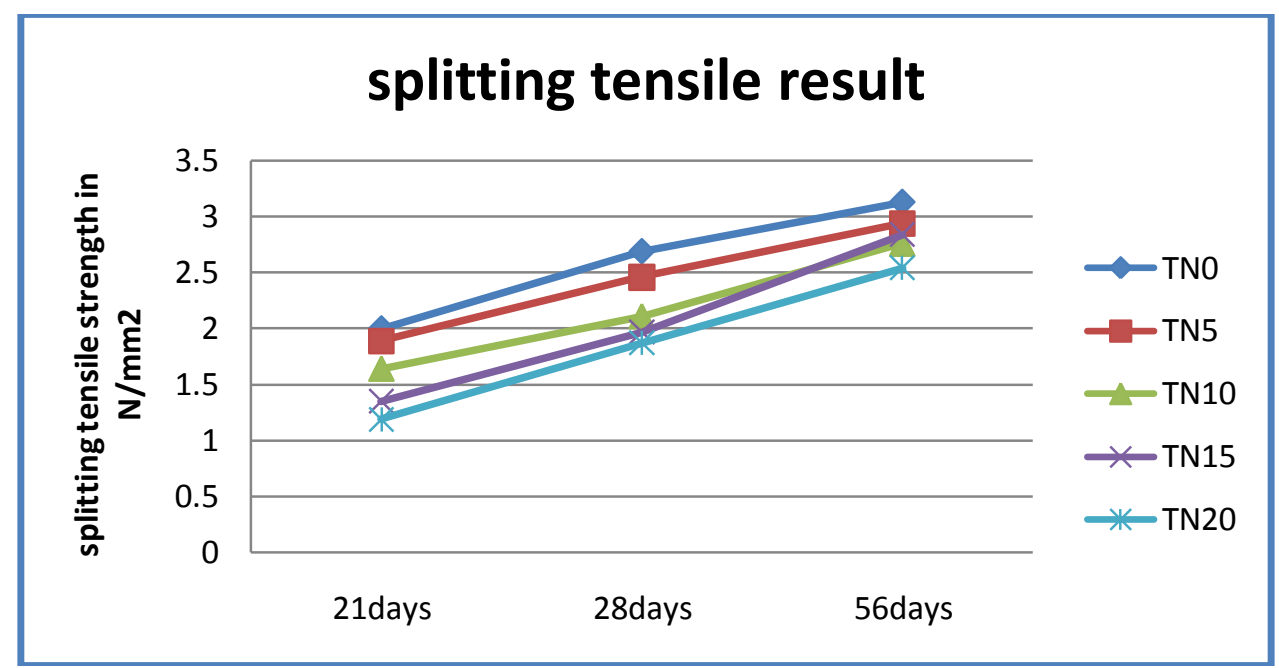

Figure 3.1: Showing splitting tensile strength of samples in water in line diagram

The results above shows that Splitting Tensile strength for the control was $2.0 \mathrm{~N} / \mathrm{MM}^{2}, 2.69 \mathrm{~N} / \mathrm{MM}^{2}$ and $3.13 \mathrm{~N} / \mathrm{MM}^{2}$ for 21,28 and 56 days respectively while it was $1.19 \mathrm{~N} / \mathrm{MM}^{2}, 1.87 \mathrm{~N} / \mathrm{MM}^{2}$ and $2.54 \mathrm{~N} / \mathrm{MM}^{2}$ for $20 \%$ GSA replacement. The results indicate that for the control (0\% GSA content) and for each cement/GSA combination, the Splitting Tensile strength increases as the age of the concrete increases.

\section{CONCLUSIONS}

From the results of the tests carried out in this work, it can be concluded that:

1. GSA is a good Pozzolanic material which reacts with calcium hydroxide forming calcium silicate hydrate. The Pozzolanic activity of GSA increases with increase of time.

2 The specific gravity of the GSA gotten was less than that of the OPC it replaced, this means that a considerable greater volume of cementitious materials will result from mass replacement.

3 The compressive strength value of the GSA/OPC blended concrete at $10 \%$ replacement level performed better and would be acceptable and considered as a good development for construction of masonry walls and mass foundations in low-cost housing in Nigeria.

\section{REFERENCES}

[1]. Nwofor T.C. and S. Sule, (2012), "Stability of groundnut shell ash (GSA)/ordinary portland cement (OPC) concrete in Nigeria" Pelagia Research Library Advances in Applied Science Research, 2012, 3 (4):2283-228).

[2]. Nagataki, S. (1994), Mineral Admixtures in Concrete: State of the Art and Trends. Special Publication, Materials Journal 144: 447-482

[3]. Alabadan et'al.(2005), .Partial Replacement of Ordinary Portland Cement (OPC) with Bambara Groundnut Shell Ash (BGSA) in Concrete. Leonardo Electronic Journal of Practices and Technologies. Issue 6, pp.43- 48, January-June 2005.

[4]. Sideris, K. K. and A. E. and Sarva, (2001), Resistance of Fly Ash and Natural Pozzolanas Blended Cement Mortars and Concrete to Carbonation, Sulfate Attack and Chloride Ion Penetration. Special Publication, Materials Journal 199: 275-294

[5]. Sengul, O. Tasdemir, C and M. A. Tasdemir. (2005), Mechanical Properties and Rapid Chloride Permeability of Concrete with ground Fly Ash. Materials Journal. 102(6): 414-421

[6]. British Standards Institution (1978), B.S. 12: Ordinary and rapid hardening Portland cement (Metric Edition). British Standards Institution, London.

[7]. Alabadan, C. F. Njoku and M. O. Yusuf (2006), "The Potentials of Groundnut Shell Ash as Concrete Admixture". Agricultural Engineering International: the CIGR E journal. Manuscript BC 05012 , Vol.VIII. February, 2006.

[8]. Raheem S.B. (2011), 'an investigation into the strength of modified concrete produced from mixes containing partial replacements of ordinary Portland cement (opc) with groundnut shell ash (gsa)'.unpublished thesis of Department of Civil Engineering, Faculty of Technology, University of Ibadan, Nigeria.

[9]. ASTM C191 (1992), Test for Time Setting of Hydraulic Cement. America Standard of Testing Material International 1916 Race Street, Philadelphia, Pa 19103, USA 
[10]. Adole et'al, (2011), Effects of Groundnut Husk Ash-blended Cement on Chemical Resistance of Concrete. 'ATBU Journal of Environmental Technology, 4, (1), December 2011'

[11]. British Standards Institution, BS 1881: Part 116 (1983) Method for determination of Compressive Strength of Concrete Cubes. London, BSI.

[12]. Kamang et'al, (2001), The Effects of Chemicals on the Properties of OPC/PFA Concrete. Nigerian Journal of construction Technology and Management 4 (1).

[13]. ASTM C618 (1994). Specification for Pozzolanas. America Standard of Testing Material International, 1916 Race Street, Philadelphia, a 19103, USA.

[14]. Bengtsson, C.P. and Whilken, J.H., Farm Structures in tropical climates: A textbook for structural Engineering and Design. FAO/SIDA Cooperative Programme. Rome: Food and Agricultural Organization, 1986. 